to the dialogue of cultures and religions in the XXI century. Articles of the St. Petersburg State Institute of Culture]. (2012).

5. Ma Changi. Illyustraciya drevnej klassiki gor i morej [Ma Changi. An illustration of the ancient classics of mountains and seas]. Gujlin': Guangxi Normal University Press. (2007).

6. O. A. Slavnikova. 2017. Moskva. EXMO. (2007).

7. O.A. Slavnikova. Ostrye strannosti mira: interv'yu Yu. Volodarskomu. 01.03.2007 // Portal o sovremennoj kul'ture "SHO" [Acute strangeness of the world: an interview with Yu. Volodarsky. 03/01/2007 // Portal about contemporary culture “SHO”]. URL: http://sho.kiev.ua/article/953 (Assessed 19.02.2014)

8. Fan Tao. SHan Haj Czin Pekin: Knizhnaya kompaniya CHzhunhua [Fan Tao. Shang Hai Jing Beijing: Zhonghua Book Company]. (2011).

9. M. N. Hramova. Specifika obraznyh predstavlenij o zhivotnom mire. Vestnik Sankt-Peterburgskogo gosudarstvennogo instituta kul'tury, [Khramova MN Specificity of figurative representations of the animal world. Bulletin of the St. Petersburg State Institute of Culture]. (2014).

\title{
Upgrade of a Fungus in Contemporary Art: From Media to Co-Author
}

\section{Bogomyakov Vladimir ${ }^{1}$, Chistyakova Marina ${ }^{2}$}

${ }^{1}$ Tyumen State University, Tyumen, Russia

${ }^{2}$ Tyumen State University, Tyumen, Russia

Corresponding author: Chistyakova Marina, mgtch@yandex.ru

Abstract. The article examines the problem of the author's potential of nonhuman agents in biological art. In the context of critical posthumanism and new ontologies, their role in the process of creating a work is being revised. Based on the example of bio-art projects, it is concluded that a performative work changes the status of a biological organism, from a medium it becomes a co-author of the artist.

Keywords: author, bioart, non-human agent, critical posthumanism 


\section{Introduction}

The digital age has inspired the transformation of almost all spheres of human activity, including art. Art \& Science, which appear as interaction of science, art and high technology, will change the understanding of author autonomy, the art work, and the viewer. Modern artists often delegate the implementation of a project (or some part of it) to various non-human agents: from computer programs to living organisms. Almost all areas of Art\&Science work with non-human agents, but he most interesting phenomena is bioart. The amount of bioart tools includes not only new technologies, but also "live" and "half-alive" media, which increases the problem of the role and functions of media in a work of art. In our opinion, in some bioart projects the media are able to become co-authors of a work. This situation re-actualizes the author's problem in the discussion field of contemporary art. Can non-human agents be considered as full co-authors of the artist?

The basis of the research is the bioart projects, the authors of which use fungi and fungi-like organisms (lat. fungi) as non-human agents. The study also analyzed the texts of Art \& Science theorists and practitioners, their interviews and public speeches where they commented on the problem of the non-human agent as a co-author. The solution to this problem requires us to look at the philosophical contexts of contemporary art and investigate how the attitude to the author's problem has changed. Next, to refer to the topic of a non-human agent as a potential co-author we will pay attention to several projects in which artists have used living systems and analyze them in the context of critical post-humanism. Then we will draw conclusions about the specifics of the artwork with a non-human agent as a potential co-author.

The philosophical context of the study. The fact that modern art turns to non-human agents is interesting. The problem of the human/non-human is one of the most discussed in the humanities. This is the most important area to bio-art than any other area of Art\&Science. Bio-art projects are a kind of intervention in the most relevant philosophical theories of our time. The ideas of critical posthumanism, agent realism, and actor-network theory are reflected in the works of modern artists. One of the unifying principles is the idea that J.-M. Schaeffer defined as the end of the "Thesis of human exclusivity" [Schaeffer, 2010, 10]: man is just a living being among others, having no superiority over other forms of life. This idea has been painfully 
maturing in the public consciousness over the past century and became the sharpest question today in the age of anthropocentricity.

The anthropocentricity is the clearest evidence for humans to rethink their position in the world. Irreversibility of the anthropogenic activity the results and its impact on a planet, forces humanity to abandon anthropocentrism as an ideology of human superiority. The rejection of the anthropocentric perspective becomes a source not only of new ontologies, in which human and non-human actors are considered similar, but also of a "new anthropology", the contours of which are written in the texts of critical posthumanism. R. Braidotti suggests considering the human as a part of a community, a "transvernal entity", completely immersed in a network of non-human relationships (with animals, plants, viruses) and immanent to this network [Braidotti, 2018, 37]. Human is not autonomous, he is symbiotic, he is always "together with-" a wide range of non-human agents. According to T. Morton: "We humans contain non-human symbiotes that are part of the system that allows us to be human, because without them we would not have lived. We are not entirely human. We co-exist with all forms of life in an indeterminate space..." [Morton, 2019, 63]. In the absence of hierarchies, the classical binary oppositions are also changed. Instead of a confrontation of nature and culture, D. Haraway introduces the concept of "natural culture" [Haraway, 2008, 250], which redefines the relationship between the human and non-human: none of these principles is ant longer a priority. It redefines the boundaries between bios ("cultural" life as a human prerogative) and zoe (natural, "animal” life).

Bio-art projects are posthumanistic. According To M. Bakke, "they direct our attention from subjective human life to non-human forms of life, such as animals, plants, microbes, and Life in general" [Wakke, 2010; 10]. Bio-art actively dwells upon the full range of problems arising from the new situation. Artists are looking for answers to questions: how can the human and non-human co-exist and interact with each other in the new situation? how can we be ethical towards each other? how does our perception of the author change in the context of the appearance of non-human agents in art?

\section{Dematerialization of the author}

In the history of culture, the author has never been understood as something clear. His voice was always mixed with something else, from God to the collective unconscious. So, in the Middle ages, the author was con- 
sidered as a kind of "media", a continuation of the "God": the real Creator was in the sphere of the transcendent. And that is why the works of that time were not signed. The concept of "author" (understood as "Creator") arose due to the growing interest in the individual, in man as a being who is able to stand on the same level with God at the beginning of the New time, thanks to the power of his mind. But after F. Nietzsche's statement of the "death of God", and the democratization of creativity initiated by the art of modernism, the author's significance begins to decline. Even Dadaists and Surrealists used such creative formats as spontaneous, collective, etc. In a situation where "everything is art" (Ben) and "everyone is an artist" (J. Boyce), artists delegate an increasing amount of creation process to the public. Thus, interactive art, the art of participation, and participatory practices allow us to interpret as a co-author any recipient who finds himself as the focus of the work.

The author, according to R. Barth, "becomes smaller, like a figure in the very depths of the literary "scene"; it is gradually removed [Barth, 1994, 387], until it completely dissolves. In his paper "The death of the author" $\mathrm{R}$. Barth describes this process in the most radical way. For Barth, the author is not a subject, he is just a scriptwriter writing down a text consisting of " quotations that refer to thousands of cultural sources" [Bart, 1994, 388]. It does not have any individual characteristics. Any work includes other voices that can be metaphorically named - the voices of culture. For M. Foucault, who continued the analysis of this problem during his talk "What is an author?" (Collège de France, 1969), the author is nothing more than a function that reflects the way certain discourses exist inside of society [Foucault, $1996,22]$. Discourses are something more fundamental than the author. In both cases, the author's identity does not matter: the author is a derivative of something external to him.

Philosophy and art have explored the author's problem from different perspectives and in different contexts, using different arguments, but they come to identical conclusions about the author's dematerialization. In contemporary art, this intention is continued by Art\&Science, which delegates copyright powers (partially or completely) not only to the public, but also to non-human agents. This gesture provokes discussion about whether these agents can be co-authors of the work. It applies to generative art, the specific feature of which is the artist's control transfer to various autonomous systems, most often technological, but in the case of bioart both technological and biological. 
Let's look at what happens to the author concept in bioart, using the example of projects whose creators use fungi and mushroom-like organisms as non-human agents.

\section{Fungi in the projects of bio-art: between media and co-author}

It is no exaggeration to say that fungi are true exponents of the spirit of our time, in the prism of posthumanism. They are the object of not only artists' close attention, but also of philosophers, anthropologists, sociologists, etc. Fungi and fungi-like organisms, in particular, slime molds, appear in films and books, which are scientific bestsellers. There are exhibitions and conferences that are devoted to fungi, and they are the object of an endless amount of laboratory research connected with science and art as well. There are whole societies of slime mold lovers, and many sites about fungi in a wide variety of contexts.

What can explain the popularity of mushrooms in modern culture? Many factors, including the fact that mushrooms have an incredible biological diversity. They are one of the dominant life forms on the planet. They can be macro - and microscopic (yeast, mold, etc.). They are ubiquitous: above and below ground, inside humans and animals, etc. as B. Woodard notes, "the fungus has the ability... to cover the entire space of civilization" [Woodard, 2016, 52]. The rhizomatic structure of the mycelium makes fungus an analog of the natural Internet. It is no accident that researchers are calling fungus the dominant biological species on the planet and metaphorically call the "fungosphere" the "thinking shell of the planet" [Shental].

But our attitude to mushrooms is ambiguous. They are a potential threat to both humans (fungal spores can cause disease) and the anthropogenic environment. Fungi destroy the inorganic and utilize the organic. Sooner or later, they will become our gravediggers, because they will have to dispose of everything that will ever die. According to B. Woodard, "the fungus is a representative of death, and not some form of life... the fungus is an agent of decomposition" [Woodard, 2016, 54]. In this context, the comparison of a radioactive cloud with a mushroom does not look strange (although some mushrooms have radiation protection). A mushroom is an alien, it is an organism that is neither a plant nor an animal, its borders are mobile. It is on the dark side of ecology. At the same time, fungi are a component of the human microbiome. Fungi are symbiotic, they are able to collaborate with representatives of other biological species, and humanity should learn 
from their example. Shental considers mushrooms as "agents of the new planetary world order" and calls for consolidation. This is a kind of allusion to the ideas of D. Haraway, who proclaimed the primary task of humanity is to form a tribe that would include "a variety of living beings, human and other, as opportunities, not completions" [Haraway]. The possibilities of this are explored today by bio-art artists.

Most artists use mushrooms in the creative process as media. In this case, the author focuses on the result, and not on the process. So, the American artist and biologist Phil Ross creates from mushrooms not only art objects, but also quite functional things - furniture, clothes, and even bricks, from which, according to the principle of the LEGO constructor, new forms can be assembled. F. Ross uses mycelium, the part a mushroom, that recycles waste containing cellulose and transforms it into an ecological material, resistant to fire and suitable for making different things. In a specially made hollow form the artist launches a mushroom, and corrects the direction of growth by putting the "feed" in the right place. After the mycelium fills the entire form, it is dried, and then processed. And the released form is ready for a new working cycle. Such relations are not called symbiotic, since the living mushroom used by the artist is killed at the end. In such cases, the artist approaches living systems from the usual positions of anthropocentrism, where there is no question of establishing any contact with a non-human form of life.

For media to be able to claim the status of an artist's co-author, the work must meet certain conditions. First of all, it should be performative. Much more interesting in this regard are interactive performative projects and installations aimed at establishing real time communication between species. The artist's focus here is on the process, not the result. These attempts are relevant to the thesis of posthumanism about the equivalence of human and non-human agents.

This idea is the basis of the project of the German artist Teresa Schubert "Growing Geometries - Tattooing Mushrooms", 2015. The work is an installation that includes live mushrooms, on the hats of which the artist put colored ink tattoos and then recorded the process of their changes (as the mushrooms grow) using videos, photos and sketches, which are also part of the project. The configuration of tattoos, which initially have geometric shapes, is transformed under the influence of the fungi life processes, the corners of the squares gradually blur and they turn into circles. Assuming that tattoos act irritatingly on the mushroom, as a kind of response gesture 
and apology to him, T. Schubert made the same tattoo, that she applied to mushrooms, on her back. This was project completion with a symbolic equating of the body of a mushroom and a human.

In Schubert's work, mushrooms create images, just as an artist does. The question of authorship in works of this kind is becoming more and more ambiguous. What is the status of the mushroom in this case? Is it a media or co - author? T. Schubert herself, who defines herself as a post-media artist, has repeatedly said in interviews and public appearances that she considers mushrooms as equal co-authors of the work. She sees her goal as "creating a situation where interaction between us makes it possible for joint creativity" [Criado and Rosell]. But the mushroom in this case behaves in full accordance with its nature. The transformation of tattoos on the mushroom cap may inspire the author, but this fact does not make him a co-author. The mushroom here rather serves as a media, although the artist herself refers to it as a co-author. Interestingly, during the interview Schubert says that she likes to think of herself and organisms as co-authors, although "researcher" and "moderator" are better terms for this kind of activity [Criado and Rosell]. At the same time, the artist's project "The Forestal Psyche" (2017), which is a series of collective walks in the forest in order to detect fungi, slime molds, lichens, and then discuss the results, nominally transfers the non-human agent to the status of a co-author. After all, the result of the walk depends on the fungi and fungi-like organisms, and each time it is not obvious, so each time this performance will be different.

Sascha Spachal, an artist from Slovenia, also works on the topic of interspecies communication. An interdisciplinary project "” ("Myconnect", 2013) created by her in collaboration with microbiologist M. Shvageli and programmer A. Podgornik, is a device for establishing human communication with oyster mushroom mycelium. R. Rapp, commenting on the artist's work, notes that she uses scientific knowledge to organize special meetings, mediated by electronic, metabolic forms of awareness and exchange-sound. Meetings of this kind "call into question the anthropocentric division between nature and man" [R. Rapp]. The audio-visual installation is a capsule with Petri dishes with mycelium fixed in the upper part of it. The person (viewer or artist) lies in the capsule; the assistant attaches sensors to various parts of his body. The human heartbeat starts the system, the signal reaches the mycelium, is processed by it and returns to the person in the form of sound, light and tactile impulses, which, in turn, cause a change in the human heartbeat 
and start a new feedback cycle (human-interface-mycelium), and so on. In this case, in our opinion, the non-human agent does not obey the strict algorithm set by nature, its reactions are variable. They not only depend on the physical condition of a person, but also have the opposite effect on him. The mushroom here, rather, acts as a co-author of the artist, who found a way to establish contact with him and responded to her in response.

This is not just an example of a symbiotic relationship between different species, but rather an illustration of the ontological equality of the human and the non-human. This is the hope that the words of A. Jing will come true, and we will be able to "build a world where ways of living are intertwined, where symbiotic transformation is still possible [Jing, 2017, 330]. The mushroom in Sasha Spachal's installation is a companion species that allows a person to experience a symbiotic relationship. According to Spachal, she owes her thoughts to a multitude of entities, human and non-human. It sees itself as an insignificant part of the planetary network and expresses the hope that we will be able to stop the metabolic gap that we have created [Saša Spačal, Mycohuman-relationships].

An example of the transformation of a non-human agent from media to co-author is, in our opinion, such bioart projects in which contact with non-human agents is achieved through music. So, the Brazilian composer Eduardo Miranda creates "Biocomputer music" (2015), which is a collaboration of the mushroom-like organism Physarum polycephalum and the composer. A biocomputer is an interactive music machine that uses bio - processors made from mold slime. While the musician is playing the piano, the pickup signals are transformed into pulses sent to the slime mold, which in turn reacts with its own impulses. These pulses are recorded by a computer program that drives the electromagnets that vibrate the strings of the instrument. The musician improvises to respond to the slime mold's response by changing the manner of performance in accordance with the set of sounds suggested by the slime mold [Miranda]. Signals coming from a non-human agent in response to human activity are transformed into the sound of music. Commenting on this project, D. M. Bulatov interprets the actions of the slime mold as an act of creativity, which is “... a clear recognition that we do not occupy any leading positions in such interaction. This is a study with an open ending, finding out what the world can offer us in response" [Bulatov, 2018, 106]. 


\section{Results and their interpretation}

\subsection{Non-human agent as co-author}

Today, we can no longer describe reality only from a human point of view. Any attempts of this kind must take into account the numerous "non-humans". In this regard, Art\&Science projects involving non-human agents, in the terminology of B. Latour, can be interpreted as a complex team of people and non-people, where the latter appear not as "passive and disenfranchised conductors of human meanings, forms and discourses", but as active intermediaries [Latour, 2014, 58]. All components of this team are capable of communication, mutual influence and transformation. The identity of the non-human agent as a co-author is not set initially and the author's task is to research it. The human initiates the change. In our view, a non-human agent can be considered a co-author of a work if the work is performative and interactive, and if the potential co-author's reactions to the author's actions are relevant, but not identical to them. They do not just cause a response from the author, but they transform him, even if it is a question of minor physical characteristics. Under the influence of these changes, the author sets new vectors for the development of the work. In this way, the non-human becomes a co-author in the dialogue process. At the same time, let's not forget that the ontology of the team's components can be different. In this regard, each time in such cases, the problem of communication arises, (which is possible to solve only if the translation problem is successfully solved). T. Nagel in a famous text asked the questions: What's it like to be a bat? What does it feel like to be a fungus, a slime mold, a bacterium? In a situation where a living organism acts as a non-human agent (in our case, mushrooms and mushroom-like organisms), a system of mutual signals exchanged by both sides can be considered as an analog of translation.

If non-human agents follow the author's plan without showing their participation, or their activity does not exceed the limits of what the author delegates to them, they remain in the status of media. If the participation of living systems declares its subjectivity, such systems become co-authors of the artist. Artist Heather Barnett notes that working with living biological material, she can predict its behavior and reactions, but cannot control the result, which allows her to view this work as almost collaborative.

The idea of treating working with non-human agents as co-creation is not shared by all artists. So, Lauren Kronemeyer, who works with insects, is skeptical about this idea: "As a human, I would not consider getting into 
the trap as cooperation" [Criado]. At the same time, she says she is "open to surprises" from the live systems she works with. The unpredictability that non-human agents demonstrate during the project process allows us to talk about them as co-authors. Their reactions can set the project in a new direction that is not intended by the original author's idea. This is why, in our opinion, most artists who work with live environments, tend to consider them as co-authors. This point of view (according to a survey of artists conducted by the editors of the online platform CLOT Magazine, dedicated to the research of art in science and technology), is shared by many artists. For example, the Israeli artist Nurit Bar-Shai is convinced that living systems have free will external to the artist, which results in a lack of control over the final result. Simon Park, an artist and microbiologist who works with slime mold and fluorescent bacteria, also sees them as co-authors, as they are, according to him, independent and able to make their own decisions [Criado]. He has his own opinion about the problem of co-authoring non-human agents, that the bacterial microbiota is able to control the production of hormones in our body and thus change our mood and mental health, so it can be argued that it is in fact the author of every work of art ever created by man. In this logic, a person acts as a co-author of a non-human agent (in this case, a microbiota), and not vice versa. It is a reason to dispute the privileged position of a person.

Bio-art projects reveal another aspect of the author's problem in contemporary art. M. Foucault in his speech "What is an author?" quotes the words of S. Beckett: "the wording of the topic with which I would like to start, I borrow from Beckett: "What difference does it make who speaks," someone said, "what difference does it make who speaks" [Foucault, 1996, 13]. In the situation of challenging the exclusivity of a human, when, in accordance with the ideas of new ontologies and posthumanism, human and non-human are equally active, there is really no difference, and in this sense the classics anticipated modernity. It doesn't matter whose voice art speaks today (human or non -human). It is important that, as P. Celan wrote, 'there are still songs to sing on the other side of humanity". Commenting on this speech by Foucault, J. Agamben notes: "There is, therefore, someone who, although remaining anonymous and faceless in it, uttered a statement - someone without whom a thesis that denies the importance of the speaker could not be formulated" [Agamben, 2014, 64]. But still, who is this "someone"? In the context of vitalistic materialism, J. Bennett's "Someone" is the result of breaking another opposition that has developed in culture: Life/Matter, 
where life was seen as the embodiment of vitality, and matter - lifelessness, passivity and inertia. J. Bennet says that the latter is replaced by a vital, "pulsating materiality that lives next to us and within us" [Bennet, 2018, 8]. Artists today work with matter as a living, self-organizing substance that reveals itself in a performative way. Both authors and co - authors are its components.

\section{Conclusions}

In modern art - performative, procedural, interactive - the state of a non-human agent is unstable: under certain conditions it can nevertheless transformed into a co-author of a work. The very fact of this upgrade, which made it possible to discuss the non-human as a potential co-author, has a huge potential. This is another step towards recognizing the non-human as a principle symmetrical to the human, and now not only in theory. As for the author's dematerialization process, it continues. The author redistributes his potential in favor of non-human agents, but this step is an invitation to interspecies cooperation.

\section{Conflict of Interest}

The authors have no conflict of interest to declare.

\section{References:}

1. Zh.-M. Sheffer. Konec chelovecheskoj isklyuchitel'nosti/ per. s fr. S. N. Zenkina [J.-M. Schaeffer. The end of human exclusivity / translation from French by S. N. Zenkin]. Moscow (2010).

2. R. Brajdotti. Kriticheskaya postgumanitaristika, ili otnosyatsya li media-prirody k prirodo-kul'turam tak zhe, kak zoe - k bios? / per. s angl. A. Pisarev, K. Poluektova-Krimer i dr. [Critical posthumanistics, or whether media-natures relate to nature culture as well as zoo - to bio-]. Opyty nechelovecheskogo gostepriimstva. [the inhuman experiences of hospitality.] V-A-C Press, Moscow. (2018). Pp. 24-41.

3. T. Morton. Stat' ekologichnym [To become ecological] / per. s angl. D. Kralechkin. Ad Marginem Press, Moscow. Muzej sovremennogo iskusstva "Garazh" [Contemporary art museum "Garazh"]. (2019).

4. D. J. Haraway. When species meet. Minneapolis: University of Minnesota Press, 2008. 421 p.

5. M. Bakke. Bio-transfiguracje. Sztuka i estetyka posthumanizmu [Bio-transfigurations. Art and Aesthetics of Posthumanism]. Wydawnictwo Naukowe UAM [Adam Mickiewicz University Press]. Poznań (2012). 
6. R. Bart. Smert' avtora.[The author's death]. Bart R. Izbrannye raboty: Semiotika. Poetika [Selected works: Semiotics. The Poetics]. Moscow (1994).

7. M. Foucault . Chto takoe avtor? [What is an author?]. Foucault M. Volya $\mathrm{k}$ istine: po tu storonu znaniya, vlasti i seksual'nosti. Raboty raznyh let [The will to truth: on the other side of knowledge, power and sexuality. Works of different years]. Moscow. (1996). Pp. 7-46.

8. B. Vudard. Dinamika slizi: zarozhdenie, i polzuchest' zhizni [Slime dynamics: occurence, and creeping of life]. Perm (2016).

9. A. Shental'. Fungofetish, fungosfera, fungocen: prizyv k sporulyacii [A. Shental. Fungophiles, fungosphere, fungocene: a call to sporulation]. http://moscowartmagazine.com/issue/39/article/778 (Accessed 18 August 2020).

10. D. Harauej. Antropocen, kapitalocen, plantaciocen, Ktulucen: sozdanie plemeni [Haraway D. the Anthropocene, capitalocene, plantatiocene, Cthulucene: creating a tribe.]. http://moscowartmagazine.com/issue/39/article/771 (Accessed 18 August 2020)

11. T. Schubert. http://theresaschubert.com/arts-experiments/art/growing-geometries-tattooing-mushrooms/\#images-videos (Accessed 15 August 2020)

12. L. Criado, M. Rosell. About Interspecific Creativity. https://www.interaliamag.org/articles/lula-criado-meritxell-rosell-interspecies-creativity/ (Accessed 15 August 2020)

13. Saša Spačal. https://www.agapea.si/en/projects/myconnect (Accessed $18 \mathrm{Au}-$ gust 2020)

14. Saša Spačal. Mycohuman-relationships https://www.agapea.si/ en/projects/ mycohuman-relationships (Accessed 15 August 2020)

15. R. Rapp. On microhuman representations: mushrooms in contemporary art research. (2019). https://doi.org/10.1186/s40694-019-0085-6 (Accessed 18 August 2020)

16. E. R. Miranda. http://neuromusic.soc.plymouth.ac.uk/ (Accessed 18 August 2020)

17. D. Bulatov. Iskusstvo kak predpolagaemoe vozmozhnoe [The art as an almost possible]. Hudozhestvennyj zhurnal [Artistic journal]. No. 106. (2018). Pp. 98-109.

18. B. Latur. Peresborka social'nogo: vvedenie v aktorno-setevuyu teoriyu / pod red. S. Gavrilenko [Rebuilding the social: introduction to actor-network-theory / edited by S. Gavrilenko]. Moscow (2014).

19. H. Barnett. Art and organism intelligence. https://www.clotmag.com/interviews/heather-barnett-art-and-organism-intelligence (Accessed 15 August 2020) 
20. S. Parc. Self-portraits: paintings with microbiotics https://exploringtheinvisible.com/2016/09/27/self-portraits-the-microbiotic-paintings/ (Accessed 15 August 2020)

21. D. Agamben. Profanacii. Moscow (2014)

22. Dzh. Bennet. Pul'siruyushchaya materiya: Politicheskaya ekologiya veshchej. [J. Bennet. Pulsating matter: the political ecology of things]. Perm (2018).

DOI 10.15826/B978-5-7996-3081-2.48

\title{
Zombie Apocalypse in Cinema as a Form of Adaptation to New Digital Technologies and Their Consequences
}

\section{Tangalycheva Rumiya}

St. Petersburg State University, Saint Petersburg, Russia rimma98@yahoo.com

\begin{abstract}
The article is devoted to the analysis of the film "Train to Busan" by South Korean film director Yeon Sang-ho, which depicts the situation of a zombie apocalypse after a chemical leak from a scientific laboratory. The director focuses on the reaction of representatives of different strata, groups and social institutions of society to the tragedy. Ultimately, the film's ideology leads to a dilemma between capitalist efficiency and social justice. These subjects are analyzed in the article from the positions of sociological approaches and concepts.

Keywords: cinema, sociology, Apocalypse, technogenic threats, future discourse, economic efficiency, social justice

\section{Introduction}

In 2016 was released the movie "Train to Busan" filmed by South Korean director Yeon Sang-ho. The film received huge box office worldwide and became the highest-grossing Korean film in Malaysia, Hong Kong and Singapore. It also received positive critical reviews. On Rotten Tomatoes, the film has a rating of $94 \%$ based on 115 reviews with an average score of 7.6 out of 10. On Metacritic, the film has a score of 72 out of 100 based on 16 critics reviews, which meets the status of "generally positive reviews".
\end{abstract}

